\title{
最近の歯学
}

\section{4. 畨科保存}

\section{歯 槽 骨 の 変 化 量 の 観 察}

\section{東京医科歯科大学第 2 歯科保存学教室 石原彰恭 木下四郎} 東京医科歯科大学柬科放射線学教室 中村 正

歯周疾患の治療を成功させるには, 術前・術後の歯槽 骨の変化を正確に把握することが，ポケットその他の臨 床所見の消長と並んで，その予後を決定する上で重要な ことである。歯槽骨の変化の観察の研究については, 臨 床的に種々の方法が現在まで行われてきているが，最为 一般的に広く行われている方法はレントゲン写真を利用 するものである ${ }^{1-4)}$ 。他の方法としては，術前・術後に 歯肉を㖵離して骨の印象をとり，その模型を分析するこ そによって変化をみている。しかし，この方法は操作が 煩雑であり，実際的ではないので特殊なケースでしか行 われていない。したがって現在までレントゲン写真を利 用する方法が数多く工夫されてきている。その中でも, デンタルX線写真を規格撮影法で経時的に撮影し，得ら れたフィルムを分析して歯槽骨量を観察する方法が多 い。規格撮影法については，多くの研究者の努力でほぼ 一定の方法が確立されていると思われる。残った問題と して, 得られたフィルムの分析方法であるが, 川崎 ${ }^{3)}$ は 歯の上に基準点を定め, その点から歯槽骨辺縁までの距 離の変化で, 歯槽骨の変化をみている。また, Plotnick ら をとり，スライドプロジェクターで拡大し，不変と思わ れる骨梁をトレースして重ね合わせ变化量を得ている。 しかしながらクレーター型欠損の初期の修復過程などの ような水平方向の骨の変化は, 高さや面積の変化として 現れないので，他の方法を用いなければならない。そこ で水平方向の骨の変化はフィルムの黒化度の变化を数値 でとらえればよいという教えが生まれ。フィルム上の 定点の黑化度の 变化 ${ }^{6)}$, 定直線上の黑化度の变化, 更 にはデンシトメーターとコンピューターを用いて二次元 の等濃度分析が行われるようになっている7-10)。しかし ながら, 分析方法が精密度を增すにつれて, 今度は分析 される写真の質が問題となってきた。そこで著者らは， 歯槽骨を覆っている歯肉に着目し，これが写真の質にど のように影響を与えているか，黒化度による観察の際に

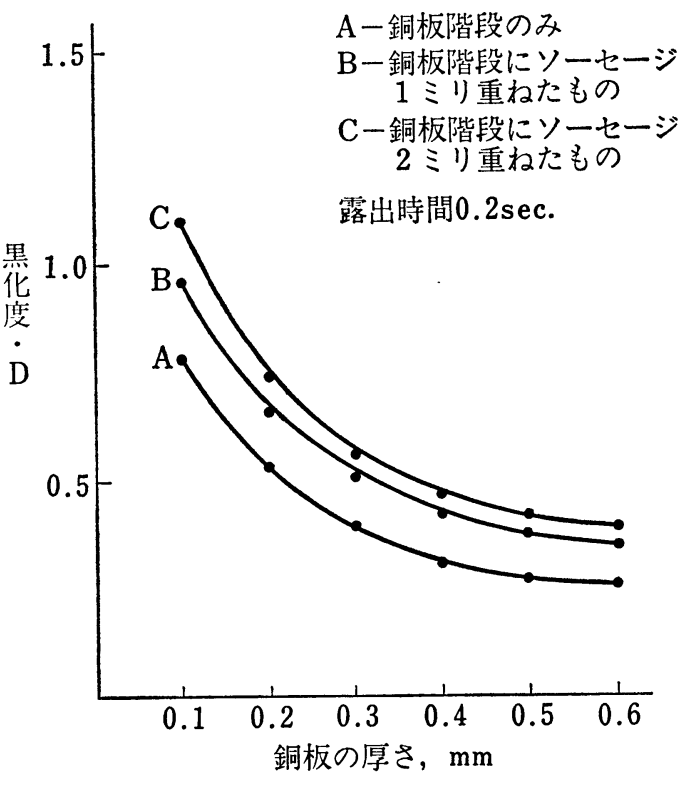

図 1

無視しても良いか否かなどについて検討した ${ }^{11)}$ 。予備 的に銅板でつくった歯槽骨つァントームの上に，歯肉フ フントームとして市販のソーセージを重ねて, 種々の条 件下で撮影したところ，図1の如くの結果となった。す なわち歯肉の存在によってフィルムの黒化度は上年して いた。一般に，X線は物質を通過することによって吸収 され，その強さを減弱し，フィルムの黒化度は低下する はずである。この逆の結果がでたことに対して，種々の 実験を追加したところ，原因は被写体から生ずる散乱線 によるといらことがわかった。また，重ね合わせた歯肉 の厚みによって黒化度は上畀したり，低下したりしてお り，その影響は一定していなかった。その結果，散乱線 の影響を除去するためには，撮影の際に照射野をできる だけ絞れば良いことがわかりこのようにして初めて歯 肉の厚みがフィルム上へ黑化度の低下として現れてく 
る。したがってこのような配慮をした撮影法でとられた フィルムでなくては，いくら精度の高い黒化度分析で雨 槽骨の変化を定量的に観察しても, 実際に迚きている变 化をとらえているとはいえないのではないかと思われ る。しかしながらまた, 歯肉というものは常に一定の厚 みをしているとは限らず，外的，内的条件の変化によっ て厚みは変化する。したがって散乱線を除去した方法で 撮影しても,フィルム上の黒化度は歯槽骨の变化と歯肉 の変化の両者の混さり合った影響を受けることになる。 つまり，歯槽骨のみの変化はフィルムの黒化度ではとら えられない。ところが歯肉の黒化度への影響を一定に規 格化できれば, 歯肉の変化は無視できると考兄られるの で, 黒化度測定によって得られた变化は歯槽骨のみのも のと考えてよい。このように分析操作の精密度が増した ためにX線写真に打いて歯肉の黒化度への影響が無視で きないレベルになってきている。著者らは, 歯肉の影響 を一定にし，骨の変化のみをとらえる方法について現在 研究を進めている。

\section{文献}

1) Harndt, E.: Das Röntgenbild des alveolar Kammes. Deutsch Zahnärztliche Z., 12: 1635-1644, 1957.

2) Patur,B. \& Glickman, I.: Clinical and röntgenographic evaluation of the post treatment healing of infrabony pockets. J. Periodontology, 33: 164 $-171,1962$.
3）川崎 化：口内法による個体 X線規格撮影とそ の歯周疾患治療への応用. 口病誌, $34: 164-180$, 1967.

4) Owings, J. R., JR. \& Fritz, M. E.: A Technique employing metallic implants for the evaluation of periodontal Surgery. J. Periodontology, 40: 661-663, 1969.

5) Plotnick, I. J., et al.: A technique for standardized serial dental radiographs. J. Periodontology, 42: 297-299, 1971.

6）茂木健司 : 抜歯創の治癒に関するX線学的並び に組織学的研究. 口病誌, 38:33-57, 1971.

7) Matsue, I., Zimmerman, E. R., Collings, C. K. \& Best, J. T.: Microdensitometric analysis of human autogenous bone implant. Two-dimensional density and pattern analysis of interproximal alveolar bone. J. Periodontology, 42: 435-438, 1971.

8) Isenberg., Goldman, H. M., Parson, F. G. \& Street, P. N.: Radiographic analysis by twodimensional microdensitometry. J. Amer. Dent. Ass., 77: 1069-1073, 1968.

9) Matsue, I., Collings, C. K., Zimmermann, E. R. \& Vail, W. C.: Microdensitometric analysis of human autogenous alveolar bone implants. J. Periodontology, 41: 489-495, 1970.

10）松江一郎, 他：歯周疾患治療に打计る骨移植の Isodensitracer による評価. 日歯保誌, $14: 111$ $112,1971$.

11）石原彰恭：X線検査による歯槽骨の客観的評価 について（軟組織の画質に及ぼす影響）。口病 誌, $43: 279-292,1976$. 